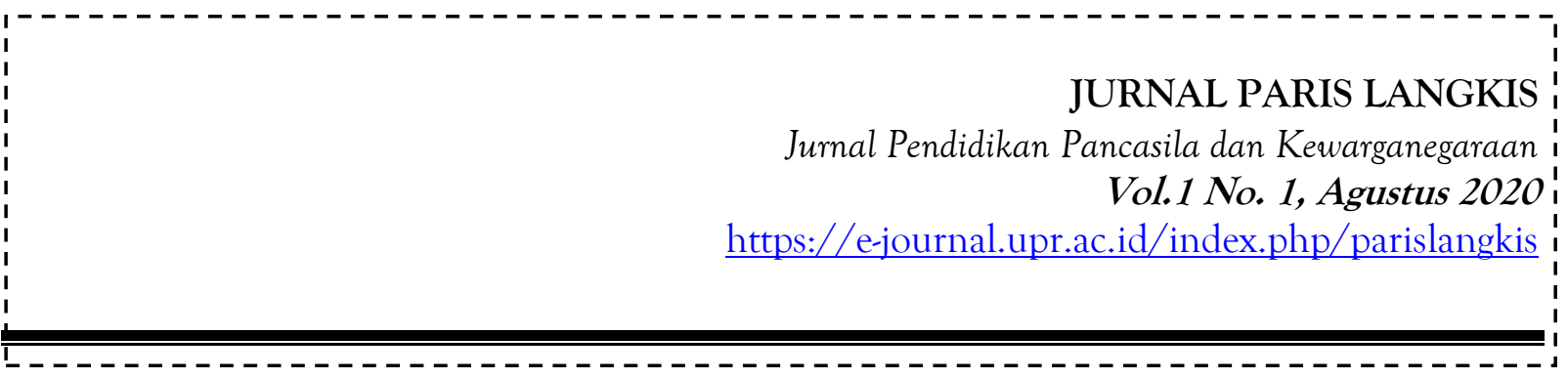

\title{
PELAKSANAAN PERKAWINAN MENURUT ADAT DAYAK NGAJU DI KECAMATAN TIMPAH KABUPATEN KAPUAS
}

\author{
Ela Novialayu ${ }^{1}$, Offeny $^{2}$, Sakman $^{3}$ \\ 1,2,3 Program Studi Pendidikan PPKn, Jurusan Pendidikan Ilmu Pengetahuan Sosial \\ Universitas Palangka Raya \\ e-mail: elanovialayu@gmail.com¹, offeny.pky58@gmail.com², sakman@fkip.upr.ac.id
}

\begin{abstract}
Abstrak:
Permasalahan dalam penelitian ini adalah mengenai Pelaksanaan Perkawinan Menurut Adat Dayak Ngaju Di Kecamatan Timpah Kabupaten Kapuas" Metode penelitian yang digunakan adalah kualitatif deskriptif." Didasarkan atas kenyataan yang sedang berlangsung sekarang dan dari 3 pasangan yang melakukan perkawinan". Berdasarkan hasil penelitian dapat di jelaskan pelaksanaan perkawinan adat Dayak Ngaju di Kecamatan Timpah Kabupaten Kapuas meliputi proses Pelaksanaan, mengetahui tujuan membangun rumah tangga hal ini memiliki fungsi untuk mengikat satu sama lainnya yang dapat memberikan dan memenuhi Syarat Perkawinan, Prosesi Pasca Perkawinan. terdiri dari beberapa tahapan yang harus dilakukan. Tahap pertama memberikan pangumbang yang termasuk dalam tahapan Hakumbangauh (lamaran); tahap kedua yaitu mamanggul atau mamupuh merupakan langkah kedua setelah hakumbang auh, mamanggul dilakukan disaksikan dihadapan semua keluarga dan pemuka adat yang menghasilkan suatu perjanjian adat dan menentukan hari pelaksanaan perkawinan, pemberian palaku atau mahar serta pemenuhan syarat-syarat yang harus disiapkan menuju Perkawinan,; tahap ketiga yaitu maja misek dilakukan antar kedua belah keluarga sebagai ucapan syukur dari keluarga lakilaki. serta mempertanyakan kesiapan dan kepastian hari yang disepakati saat mamanggul;tahap keempat yaitu Perkawinan Adat secara Adat Dayak Ngaju yang mempunyai tujuh belas item yang dipenenuhi oleh pihak laki-laki yang disebut paramun pisek, paramun hadat kawin dan tahapan terakhir seperti gong, pelaku dll. dalam pelaksanaan perkawinan menurut adat Dayak Ngaju yaitu Pakaja Manantu dimana tahapan ini dilakukan setelah proses pelaksanaan perkawinan telah selesai.
\end{abstract}

Kata Kunci : Dayak Ngaju; Perkawinan; Adat

\section{Abstract:}

The problem in this study is regarding the Implementation of Marriage According to Dayak Ngaju Customs in the District of Taya Kapuas District "The research method used is descriptive qualitative." Based on the reality that is ongoing now and of the 3 couples who are married ". Based on the results of 
the study can be explained the implementation of Dayak Ngaju traditional marriages in the District Taya Kapuas District includes the implementation process, knowing the purpose of building a household it has a function to tie each other which can provide and fulfill the Marriage Requirements, Post-Marriage Procession, consists of several stages that must be carried out. The first stage provides contributors who are included in the Hakumbangauh (application) stage; all families and traditional leaders who produce a customary agreement and determine the day of the marriage, the giving of my head or the bride price and the fulfillment of the conditions that must be prepared for marriage; thanksgiving from a family of men. as well as questioning the readiness and certainty of the day agreed upon at mamanggul, the fourth stage, namely Indigenous Marriage in Dayak Ngaju which has seventeen items that are fulfilled by men called paramun pisek, paramun marath and the last stages such as gongs, perpetrators etc. in the implementation of marriage according to the Dayak Ngaju tradition, Pakaja Manantu where this stage is carried out after the marriage process has been completed.

Keywords: Ngaju Dayak; Marriage; Adat

\section{A. PENDAHULUAN}

Salah satu kebutuhan manusia adalah hidup bersama antara pria dan wanita(Nurhajati $\&$ Wardyaningrum, 2014). Faktor yang penting keinginan untuk hidup bersama terutama untuk memperoleh keturunan, konsekuensi dari hidup bersama dalam sebuah perkawinan akan menimbulkan beberapa akibat hukum yang sangat penting dalam masyarakat yaitu; Pertama, bahwa dengan hidup bersama antara seorang pria dan wanita yang disebut suami isteri, kedua hidup bersama dalam sebuah ikatan perkawinan yang sering disebut dengan rumah tangga(Matondang, 2014). Dalam masyarakat membutuhkan suatu aturan yang mengatur perilaku dalam hidup bersama, diantaranya mengenai tata cara pelaksanaan dan syarat-syarat untuk sahnya hidup bersama tersebut. Untuk sahnya hidup bersama sebagai suami isteri pada dasarnya harus didahului dengan suatu upacara-upacara tertentu yang biasanya disebut dengan upacara perkawinan adat, sehingga perkawinan itu merupakan suatu momen penting bagi suami sebagai suatu ikatan yang akan melahirkan hak dan kewajiban antara satu dengan yang lainnya beserta kewajiban yang timbul dari suatu perkawinan tersebut dalam perkawinan yang dianggap sakral menjalin ikatan atau hubungan sehidup semati sempai maut yangmemisahkan dalam istilah adat dayak ngaju sering disebut "Sinta hentang Tulang" atinya dalam membina rumah tangga hendaknya seumur hidup. Perkawinan juga membangun upaya menjaga toleransi dalam kerukunan umat bergagama. Perkawinan yag dilandasi atas niat untuk membina rumah tangga yang baik harus melalui administrasi yang baik dan ketulusan bersama membangun rumah tangga, jika tidak maka bisa berakibat pada keretakan rumah tangga sehingga berakibat pada anggota keluarga yang ada. Salah satu akibat yang ditimbulkan adalah kurangnya perhatian kepada anak, yang membawa anak pada lingkungan yang salah(Saefulloh, 2018). Peranan pemerintah juga berpernan aktif dalam mencatat perkawinan di catatan sipil bahkan adat juga mencatat berdasarkan aturan hukum adat yang berlaku terutama pada pemenuhan hukum adat Dayak Ngaju(Normuslim, 2018).

\section{B. KAJIAN TEORI}

Peraturan perkawinan yang merupakan suatu kesatuan yang berlaku bagi seluruh lapisan masyarakat di Indonesia diatur dalam Undang-Undang Nomor 1 Tahun 1974 tentang perkawinan serta Peraturan Pemerintah Nomor 9 Tahun 1975. Perkawinan menurut adat pada

\section{Paris Langkis}


saat sekarang ini lebih dominan dilakukan oleh kalangan masyarakat pedesaan, termasuk masyarakat desa yang ada di desa(Santoso, 2016). Dengan masih dipergunakannya tata cara perkawinan menurut adat istiadat sudah barang tentu hal ini akan menimbulkan berbagai masalah dalam sebuah rumah tangga dilihat dari perspektif hukum di Indonesia. Di Indonesia, mengenai perkawinan telah ada aturan yang mengaturnya yaitu Undang-Undang Nomor 1 Tahun 1974 tentang perkawinan yang dimuat dalam Lembaran Negara Nomor 309 dan diatur pelaksanaannya pada Peraturan Pemerintah Nomor 9 Tahun 1975. Undang-Undang tersebut merupakan salah satu hukum nasional yang diundangkan pada tanggal 2 Januari 1974 dan dinyatakan berlaku secara efektif pada tanggal 1 Oktober 1975.

\section{METODE PENELITIAN}

Metode penelitian penulis adalah kualitatif deskriptif yaitu jenis penelitian yang menghasilkan data deskriptif berupa kata-kata tertulis atau lisan dari orang-orang dan perilaku yang dapat diamati. Pengumpulan data melalui observasi dan wawancara menggunakan teknik pengumpulan purpossive sampling. Dalam hal ini penulis akan mendekripsikan secara detail terhadap pelaksanaan perkawinan menurut adat dayak ngaju di kecamatan timpah kabupaten kapuas.

\section{HASIL DAN PEMBAHASAN}

\section{Proses pelaksanaan perkawinan adat Dayak Ngaju di Kecamatan Timpah Kabupaten} Kapuas

Perkawinan menurut adat Dayak Ngaju sudah ada sejak dahulu kala dan masih di lestarikan sampai sekarang oleh anak cucu suku Dayak Ngaju yang berasal dari isyarat Pelek Ruji Pangawin bapa Sangomang atau yang dikenal dengan perjumpaan Manyamei dengan Putir (Mitologi Dayak Ngaju) yang dijadikan sebagai teladan perkawinan yang paling sempurna bagi suku Dayak Ngaju.

Dalam sistem perkawinan suku Dayak ada beberapa tahapan dan proses yang dilalui secara Adat Dayak Ngaju yang berada di Kecamatan Timpah. Sebelum terjadinya perkawinan antara kedua calon pengantin maka ada beberapa tahapan dan proses yang dilakukan seperti yang dikemukakan oleh Bapak Model sebagai Mantir adat di Kecamatan Timpah mengatakan : "Kami terlebih dahulu penjelasan tentang kawin adat, tata cara perkawinan sesuai dengan aturan yang telah diatur dari dulu, iyalah di awal perkawinan yaitu hakumbang auh dari pihak lelaki memberikan uang hakumbang untuk keluarga wanita bila diterima iyalah arti memunjak untuk hapanggul inilah namanya yang hapanggul dan seperti yang dikatakan tadi dihapanggul masih ada orang tua kedua belah pihak lelaki dan wanita masih disebut calon mempelai di hapanggul bila masih hakumbang masih belum ada surat perjanjian bila sampai gagal uang pengumbang tadi dikembalikan dan bila panggul sudah tertulis dan ada dendanya/sanksinya. Proses-proses atau tahapan yang saya sebutkan diatas uga termasuk dari tahapan juga karena sehabis panggul itu didalamnya ada perjanjian untuk pelaksanaan yang nikah secara adat dayak ngaju yang biasa disebut dengan pemenuhan hukum adat ada batas waktu 3 bulan janji pelaksanaan perkawinan yang sah yang disebut bayar hadat jalan. Peran mantir memang secara aturan berperan tentunya karena ini masalah adat kawin dari tingkat desa tapi memiliki kerja sama dengan perangkat RT/Perangkat Desa dan yang sangat berperan lembaga adat. Dan sangat sulit digantikan karena sangat berperan lebih. apa yang harus dipersiapkan ialah terutama 
menyiapkan diri supaya acara berjalan lancer dan bagus dengan ketentuan yang ada dikedua belah pihak dan juga termasuk beberapa keluarga yang ada hanya itu yang bisa soalnya perkawinan banyak memiliki kesiapan terutama kita lihat biasa acara bila ada hiburan/musik fokok karena kesiapan dan kedudukan pelaminan harus dipersiapkan kedua belah pihak misalnya cuman acara adat langsung kerumah kedua belah pihak lelaki atau wanita dan yang lainnya yang kita tau acara penganten yang harus disediakan sampai semua dana karena punya ada tidak bisa diganggu gugat. Tamping tawar adalah pengukuhan yang dimiliki adat bahwa penganten sah diresmikan oleh adat dan terakhir sudah dari kami sebagai dewan adat pasti sudah ada surat menyurat kawin. Syaratsyarat ia seperti yang saya bilang tadi seperti dana dan sebagainya itu juga sesuai kemampuan dari kedua belah pihak dan tidak bisa memaksakan keadaan banyak sedikitnya tidak bisa dipaksakan karena itu sesuai kesepakatan kedua belah pihak kami sebagai dewan adat hanya melaksanakan karena ada 2 hal dan dulu ada 3 hal yang pertama acara adat, agama, dan melaluskan acara karena dulu catatan sipil dan sekarang jarang yang harus adat dan agama yang sekarang itu biasa ada pekaja menantu itu memiliki acara khusus setelah kawin, yang saya lihat dari situ tidak ada yang terlalu banyak karena arti dari ini sendiri menantu perempuan yang datang ke tempat lelaki yang wanita tidak bisa langsung ketempat lelaki/mertuapihak lelaki hanya perlu menyiapkan tamping tawar dan batu kaja hanya itu yang berkesan untuk pihak wanita dan hal ini adalah sebagai acara ucapan syukur dari dulu. makna itu supaya mencikupi syarat yang ada dan sebagai ucapan syukur dari pihak martua karena sudah memiliki menantu."(Wawancara, 12 Mei 2019).

Kemudian pendapat serupa juga disampaikan oleh Bapak Buder sebagai Damang yang mengatakan bahwa: "Yang pertama ada 4 tahap yang pertama hakumbang auh apabila diterima oleh pihak perempuan dan pihak lelaki menuntut uang penggul yang artinya bahwa sudah dipatok sebagai tanda yang akan dilaksanakan sampai waktu maja misek menentu tgl kawin dan sebagainya setelah itu positif baru akan dilaksanakan proses pernikahan jadi tahap yang dilalui ada 4 proses sama dengan tahap ini tadi adat dayak ngaju”. (Wawancara, 19 Mei 2019).

Berdasarkan pendapat diatas dapat diuraikan tentang tahapan dan langkah-langkah perkawinan adat Dayak Ngaju dan berikut tahapannya. Pertama proses Hakumbang auh merupakan tahapan awal yang harus dilalui oleh masyarakat Dayak Ngaju jika ingin melakukan pernikahan maka terlebih dahulu ada proses awalnya yang mungkin dikenal dimasyarakat umum adalah lamaran dengan berbagai syarat uang pengumbang, gong, seserahan, dan menyiapkan dana yang telah disesuaikan dan disetujui kedua belah keluarga. Dalam Hakumbang auh terlebih dahulu calon pengantin laki-laki memberikan duit pangumbang sebagai simbol dan pesan bahwa ada seorang laki-laki yang ingin mempersunting/menyuntingnya sebagai seorang istri. Sehingga bilamana diterima maka akan dilanjutkan ke proses selanjutnya. Untuk pemberian uang atau duit pangumbang tidak boleh diantar oleh calon mempelai laki-laki melainkan harus melalui seorang perantara yang disebut dengan Luang (pelantara) yang sudah dikenal oleh keluarga kedua belah pihak seperti teman atau sahabat yang bisa menjaga rahasia dan sampai sekarang masih berlaku dan tetap dipertahankan. Mengapa demikian karena harus dijaga kerahasiaannya agar menjaga harkat dan martabat laki-laki untuk diantisipasi jika duit pangumbang tidak diterima maka keluarga dari pihak laki-laki tidak menanggung malu. Mengenai duit pangumbang yang diberikan serta jarak untuk mengetahui diterima atau tidaknya lamaran tersebut biasanya tidak boleh dari empat puluh hari lamanya seperti yang dikemukakan oleh Bapak Model sebagai Mantir Adat mengatakan : "jarak untuk pihak keluarga perempuan memberikan jawaban terhadap duit pangumbang atau lamaran tersebut tidak

\section{Paris Langkis}


boleh terlalu lama menggantung orang, jarak tersebut paling cepat tiga hari dan paling lama empat puluh hari". (Wawancara, 12 Mei 2019).

Berdasarkan pernyataan di atas maka dapat kita ketahui mengapa tidak boleh melebihi dari empat puluh hari itu dilakukan agar pihak laki-laki cepat untuk mengetahui diterima atau tidaknya lamaran tersebut. Jika duit pangumbang tersebut dikembalikan maka artinya lamaran tersebut ditolak oleh pihak perempuan, dengan begitu pihak perempuan dapat mengembalikan duit pengumbang ini tadi ke pihak lelaki dengan cara memanggil orang yang dipercaya ini tadi yang biasa disebut sebagai pelantara tadi dilakukan secara tersembunyi melainkan melalui perantara dengan cara berbisik. Namun jika duit pangumbang diterima itu mempunyai arti bahwa lamaran diterima dan duit pangumbang tersebut yang diberikan dan akan diperhitungkan dalam biaya perkawinan yang akan datang. Jika tiba-tiba dikemudian hari pihak laki-laki atau pihak perempuan mengundurkan diri dalam masa Hakumbang Auh, maka duit pangumbang atau benda tadi secara otomatis akan hilang dan sepenuhnya dikuasai oleh pihak perempuan.

Setelah melalui dan terlaksananya proses dan tahapan dalam perkawinan suku Dayak Ngaju yang pertama maka akan ada tahapan selanjutnya yang disebut dengan maja misek seperti yang dikemukan oleh bapak Model mengatakan bahwa "jika telah terlaksana Hakumbang auh dan telah diterimanya lamaran atau duit pangumbang tadi, maka dalam proses hakumbang dan disebut juga mamanggul atau panggul terjadi sebuah perjanjian adat yang disaksikan oleh pihak keluarga dan pemuka adat lainnya" (Wawancara, 12 Mei 2019).

Lebih lanjut Damang Kecamatan Timpah mengatakan kelengkapan dari jalannya proses adat perkawinan Dayak Ngaju diKecamatan Timpah yang sudah sering dilaksanakan oleh masyarakat setempat tentu bukan hanya memberikan duit pangumbang dan sebuah perjanjian saja, namun ada beberapa syarat yang dipersiapkan sebagai berikut: "harus memenuhi keriteria yang ditentukan dan menyiapkan segala sesuatu yang diperlukan seperti seserahan, uang pengumbang, gong dan memiliki dana yang sudah disesuaikan kedua belah pihak dan yang sudah disetujui". (Wawancara, 19 Mei 2019).

Mengenai pendapat di atas juga diperkuat oleh pasangan yang sudah melakukan perkawinan secara adat Dayak Ngaju di Kecamatan Timpah yang bernama Niki dan Ramona mengatakan proses pelaksanaan misek sebagai berikut : "proses yang saya lakukan adalah dengan adanya melengkapi segala proses yang ada dan menyiapkan segala keperluan sebelum acara nya berlangsung yang pertama ada tahap-tahap yang dilalui pertama hakumbang auh apabila diterima oleh pihak lelaki dan pihak lelaki menuntut uang penggul yang artinya bahwa sudah dipatok sebagai tanda yang akan dilaksanakan sampai waktu maja misek menentu tgl kawin dan sebagainya setelah itu positif baru akan dilaksanakan proses pernikahan"(wawancara, 22 Mei 2019).

Berdasarkan hasil wawancara dan hasil pengamatan peneliti selama tinggal di Kecamatan Timpah mengenai proses dan tahapan perkawinan suku Dayak Ngaju mulai dari Hakumbang Auh menuju tahapan maja misek, Hapanggol dan sampai acara perkawinan dan sacara setelah perkawinan dengan berbagai ketentuan dan syarat yang akan peneliti coba uraikan bahwa beberapa syarat dan benda yang telah dipersiapkan setelah diterima pihak perempuan, maka benda adat yang dibawa oleh pihak laki-laki akan di Palas dengan telur ayam atau juga dikenal dengan sebutan Tampung Tawar dan akan diadakannya syukuran sekaligus mengundang pemuka adat untuk menyaksikan secara terbuka acara pertunangan tersebut yang dikomando oleh Mantir adat dan keluarga lainnya. Secara garis

\section{Paris Langkis}


besarnya pihak perempuan dengan utusan kerabat dari keluarga pihak laki-laki akan membicarakan hal-hal antara lain seperti penentuan hari perkawinan, besarnya jujuran atau disebut juga Palaku, biaya perkawinan, syarat-syarat adat yang dipenuhi dan surat perjanjian adat.

Jika dalam pembicaraan saat maja misek dilakukan mendapatkan kata sepakat, maka sejak hari itu antara laki-laki dan perempuan tersebut telah resmi bertunangan dan bendabenda Paramu Misek yang dibawa oleh pihak laki-laki tadi ditinggal dan diserahkan kepada pihak perempuan. Seperti yang dikemukakan oleh Mantir Adat Kecamatan Timpah yaitu : "Paramu misek dan paramun adat yang telah dibawa oleh laki-laki untuk perempuan maka tidak boleh dibawa pulang dan akan resmi menjadi syarat dan pamaun misek dan menjadi milik pihak perempuan". (Wawancara, 12 Mei 2019). Pendapat diatas juga dibenarkan oleh pasangan pengantin Niki dan Ramona yang mengatakan bahwa : "saat pelaksaan perkawinan dan paramun misek yang dibawa oleh pihak laki-laki maka akan diserahkan sepenuh nya kepada pihak perempuan dengan berbagai kesepakatan yang diucapkan dihadapan keluarga kami" (Wawancara, 22 Mei 2019).

Kemudian hal di atas sejalan dengan yang dikatakan oleh Damang Kecamatan Timpah yang mengatakan bahwa : "saat pelaksanaan pertunangan atau disebut dengan misek,pihak lakilaki bukan hanya membawa paramun misek, namun juga terdapat beberapa perjanjian yang mengikat dalam sebuah perjanjian adat yang dipimpin oleh Mantir Adat secara tertulis" (Wawancara, 19 Mei 2019).

Berdasarkan hasil wawancara di atas peneliti mencoba menguraikan lebih rinci mengenai jalannya proses misek dalam hakumbang auh yang dilakukan oleh masyarakat adat Dayak ngaju dalam pelaksanaan perkawinan adat Dayak. Pertunangan yang dilakukan akan menjadi kuat dan mengapa harus ada surat penjanjian adat yang berisi larangan dan seruan yang boleh dilakukan oleh kedua belah pihak laki-laki dan perempuan dalam sebuah ikatan perjanjian adat yang mempunyai konsekuensi hukum baik hukum formal maupun hukum adat setempat yaitu hukum adat Dayak Ngaju dengan ditentukannya suatu syarat denda oleh pihak mana yang membatalkan atau mencorang dalam artian ada kata penghianatan atau masuknya orang ketiga, maka pihak yang membuat dan melanggar perjanjian akan dikenakan sanksi adat berupa Jipen.

Lebih lanjut mengenai tahapan pelaksanaan perkawinan menurut suku Dayak Ngaju di Kecamatan Timpah setelah melalui proses adat hakumbang dan disebut juga sebagai langkah misek atau meminang. Setelah terjadi kata sepakat antar kedua belah pihak dilanjutkan dengan proses lainnya yang disebut dengan Mamanggul atau Mamupuh merupakan kelanjutan dari Hakumbang Auh seperti yang dikemukan oleh Model Mantir Adat Kecamatan Timpah mengatakan bahwa : "Mamanggul sebenarnya masih termasuk dalam tahap hakumbang namun mamanggul dilakukan setelah ada kesepatakan terjadi sehingga muncullah kata mamanggul atau mamupuh petak yang kami jadikan sebagai bahasa kiasan orang Dayak seperti pihak laki-laki memberikan pernyataan tujuan kedatangan kami kesini ingin menebas ladang tanah dan memberikan tanda palang kayu kecil pada ladang tersebut dengan tujuan bahwa ladang tersebut sudah ada yang memiliki". (Wawancara, 12 Mei 2019).

Berdasarkan pendapat di atas mengenai makna mamanggul atau mamupuh memberikan sebuah isyarat dan tanda bahwa bilamana seorang perempuan yang sudah dipanggul oleh seorang laki-laki berarti perempuan tersebut tidak boleh lagi diganggu dan itu artinya sudah ada yang memiliki. Lebih lanjut mengenai hal di atas Damang Kecamatan 
Timpah memberikan pernyataanya mengenai jalannya mamanggul atau mamupuh yaitu "dalam acara mamanggul pihak laki-laki dan perempuan harus sudah mempunyai kesepakatan dan disaksikan oleh para orang tua calon pengantin. Kelangkapan acara mamanggul yang harus dipersiapkan cukup dengan uang atau disebut dengan Batu Panggul dengan nilai Jipen Rp. 100.000. , dengan kelengkapan lainnya sesuai dengan keringanan hati dari pihak laki-laki". (Wawancara, 19 Mei 2019).

Berdasarkan pernyataan di atas mengenai mamanggul atau mamupuh dilakukan agar tujuan dan hajatan serta niatan baik itu dapat terlaksana dengan baik maka diterbitkanlah juga surat perjanjian panggul seperti; Biodata orang tua masing-masing, biodata kedua calon pengantin, agama yang dijadikan dasar perkawinan, tempat dan tanggal pelaksanaan, para saksi dan rincian jalan adat yang akan dibayar oleh calon mempelai laki-laki pada hari perkawinan nanti serta batu panggul yang digantikan dengan uang.

Dalam perkawinan adat Dayak Ngaju dikenal dengan beberapa tahapan setelah terlaksananya komponen Hakumbang Auh dan mencapai titik kesepakatan dalam penentuan hari pelaksanaan dan lainnya. Dalam proses menuju pelaksanaan perkawinan adat biasaya dilakukan tahap selanjutnya yaitu dikenal dengan Maja Misek. Seperti yang dikemukakan Bapak Model selaku Mantir Adat di Kecamatan Timpah mengatakan bahwa: "Maja Misek dilakukan bertujuan untuk mengklarifikasi dan memastikan hari pelaksanaan perkawinan yang ditentukan saat proses meminang sebelumnya apakah ada perubahan hari tanggal dan sekaligus mengecek kesiapan pihak perempuan dalam menyambut pelaksanaan pesta perkawinan adat". (Wawancara, 12 Mei 2019).

Berdasarkan pendapat di atas bahwa dilakukannya maja misek oleh pihak keluarga laki-laki datang bertamu ke rumah pihak perempuan untuk membiacarakan sejauh mana persiapan yang dilakukan serta koordinasi antar kedua belah pihak menyambut pelaksanaan perkawinan. Maja misek dilakukan juga bertujuan untuk mengkonfirmasi pembicaraan yang dibuat saat pelaksanaan Hakumbang dengan beberapa pertanyaan seperti apakah ada perubahan hari atau tanggal, tempat dan kesiapan lainnya demi kelancaran pesta perkawinan dan menghindari salah komunikasi walaupun saat ini sudah ada tersedia alat komunikasi seperti handphone dan lainnya, namun kebanyakan masyarakat Dayak Ngaju khsususnya daerah Kecamatan Timpah dan pedesaan lainnya masih melakukan hal tersebut dengan alasan menjalankan adat dan tradisi suku Dayak.

Setelah dilakukannya maja misek dan mempunyai kepastian hari tanggal dan tempat, maka berbicara waktu antara Maja Misek dengan pelaksanaan kawin adat tidaklah terlalu lama yang berkisar tiga sampai satu pekan lamanya. Namun dalam pelaksanaan kawin adat juga mempunyai langkah dan syarat adat yang harus dipersiapkan yang disebut dengan Paramun Adat Kawin (Kelengkapan adat perkawinan) seperti yang dikemukan oleh Bapak Model selaku Mantir adat mengatakan : "dalam pesta perkawinan maka terlebih dahulu pihak keluarga mempersiapkan paramun kawin adat seperti Gong, Rotan Sigi, Daun Sawang, Batang Sumpit, Sanaman pangkit, Batu asa, amak, tanteloh, air tampung tawar, undus bangkang, tanah biasa, lilis lamiang, behas buwur dan uang logam". (Wawancara, 12 Mei 2019). Hal serupa juga juga dikemukakan oleh Bapak Buder selaku Damang Kecamatan Timpah membenarkan hal di atas yaitu: "pelaksanaan perkawinan orang Dayak bukan hanya sekedar menjalankan pesta namun ada syarat dan barang yang diadakan seperti paramun perkawinan yang terdiri dari empat belas item, namun jika item tersebut tidak ada atau sulit didapatkan maka bisa digantikan dengan 
yang lain dan harus mendapatkan persetujuan dari pihak keluarga perempuan" (Wawancara, 19 Mei 2019).

Berdasarkan hasil wawancara di atas mengenai persiapan pesta perkawinan juga harus menyiapkan paramun kawin adat yang mempunyai arti kelengkapan perkawinan adat yang terdiri dari empat belas point atau nama benda seperti:

1. Gong digunakan untuk tempat duduk kedua mempelai pengantin

2. Rotan sigi sepanjang kurang lebih dua meter

3. Daun sawang

4. Batang sumpit kawit kalakai

5. Sanaman pangkit yaitu pisau untuk digigit

6. Batu asahan pisau

7. Amak uwei yang digunakan untuk alas duduk

8. Tanteloh atau telor ayam yang digunakan untuk manyaki mamalas pengantin

9. Air tampung tawar dan minyak wangi untuk membilas wajah pengantin

10. Minyak kelapa untuk campuran bahan tampung tawar

11. Tanah biasa yang dicampurkan ke dalam air tampung tawar

12. Lilis lamiang untuk ikat tangan kedua mempelai

13. Beras untuk dihamburkan

14. Duit ringgit atua uang logam

(Hasil wawancara dari Damang Adat dan Mantir Adat).

2. Tujuan, fungsi, syarat perkawinan menurut adat Dayak Ngaju di Kecamatan Timpah Kabupaten Kapuas

Perkawinan menurut adat Dayak Ngaju memiliki Tujuan, fungsi, dan Syarat perkawinan tersendiri yang sudah menjadi tradisi dari dulu dan sampai sekarang masih dilestarikan sedemikian rupa agar tidak hilang begitu saja.

a. Tujuan perkawinan menurut adat Dayak Ngaju di Kecamatan Timpah Kabupaten Kapuas.

Dalam pandangan adat Dayak Ngaju tujuan dari perkawinan itu sendiri adalah untuk membina kerukunan kehidupan dan untuk mencapai kesejahteraan keluarga dengan maksud ingin mempertahankan, meneruskan keturunan dalam upaya menjaga kelestarian dan kekerabatan keluarga karena

b. Fungsi perkawinan menurut adat Dayak Ngaju di Kecamatan Timpah Kabupaten Kapuas.

Perkawinan memiliki fungsi untuk mempersatu kedua keluarga dan mendapat keturunan, supaya mengikat satu sama lain agar tidak terjadi perjinahan,karena pernikahan adalah ikatan suci dari yang Maha Kuasa. Maka dengan adanya hal seperti ini tradisi adat Perkawinan Dayak Ngaju memiliki keunikan tersendiri dengan semua itu memiliki makna tersendiri, adanya hal seperti ini pihak keluarga dan calon mempelai harus menyiapkan syarat yang telah ditentukan meskipun ada beberapa yang tak bisa dipenuhi bisa digantikan sesuai dengan kesepakatan pihak Adat dan keluarga . Selain paramun adat kawin lebih lanjut Bapak Model selaku mantir adat menjelaskan mengenai Jalan Hadat Kawin (ketentuan adat kawin) yang menjadi bagian dari jalannya proses pelaksanaan perkawinan adat Dayak Ngaju mengatakan bahwa : "bilamana laki-laki ingin menikah maka terlebih dahulu harus memenuhi syarat jalan adat perkawinan seperti menyiapkan beberapa bentuk benda adat seperti Palaku, saput, seperangkat pakaian, sinjang entang, lapik luang, garantung kuluk pelek, lamiang turus pelek, bulau singgah pelek, lapik ruji, timbuk tangga, tutup uwan, pinggan pananan

\section{Paris Langkis}


pahinjean kuman, rapin tuwak,bulau ngandung, jangkut amak, turus pelek dan batu kaja". (Wawancara, 12 Mei 2019).

Berdasarkan hasil wawancara di atas mengenai jalannya pelaksanaan perkawinan paramun adat yang terdiri dari tujuh belas syarat yang harus dipersiapkan oleh pihak lakilaki dengan berbagai makna dan tujuan. Adapun makna dari ketujuh belas persyaratan paramun adat kawin sebagaimana dapat menurut penelitian bersama Damang dan Mantir adat uraikan antara lain yaitu:

1. Pelaku (mas kawin)

2. Saput/ kain 1 lembar Saput (satu potong pakaian atau uang)

3. Pakaian kain 1 lembar pakaian

4. Sinjang entang (kain panjang)

5. Lapik luang (lapisan alas mangkok besar)

6. Lamiang turus pelek (Lilis Lamiyang)

7. Duit lapik ruji

8. Pinggan panan (seperangkat alat makan/minum)

9. Timbuk tangga (duit turus)

10. Jangkut amak (seperangkat tempat tidur)

11. Rapin tuak, (minuman keras)

12. Batu kaja

13. Bulau kandung / panginan jandau (biaya dalam pesta perkawinan)

14. Tutup Uwan dua meter kain hitam sebagai wujud hormat terhadap nenek moyang mempelai perempuan dan

15. Saput berupa berupa barang atau kain sebagai penghormatan kepada saudara ipar.

Lebih lanjut mengenai perkawinan adat Dayak ngaju di kecamatan Timpah Kabupaten Kapuas. Berdasarkan pengamatan peneliti dilapangan dalam setelah terpenuhinya syarat perkawinan yang dilakukan maka akan sampai pada acara pelaksanaan perkawinan seperti yang dikemukakan oleh Bapak Model selaku Mantir Adat mengatakan : "Jalannya perkawinan adat Dayak ngaju yang terjadi di Kecamatan Timpah dan masyarakat Dayak pada umumnya yaitu dimulai dari pengantin Haguet dan Pengantin Lumpat". (Wawancara, 12 Mei 2019).

Hal di atas juga dibenarkan oleh Pasangan yang baru menikah yaitu Niki dan Ramona mengatakan : "saat pelaksanaan pernikahan adat saya juga begitu setelah terpenuhinya persyaratan hingga sampai upacara pelaksanaan perkawinan yang disebut pengantin Haguet dan Pengantin Lumpat" (Wawancara, 22 Mei 2019).

Dari pernyataan di atas dapat diuraikan bahwa jalannya upacara pelaksanaan perkawinan adat Dayak ngaju dimulai dari pengantin Haguet yang berarti pada hari yang telah ditetapkan keluarga pengantin laki-laki dan semua keluarga serta sahabat yang telah diundang berkumpul kembali di rumah mempelai laki-laki untuk bersama-sama mengantar keberangkatan pengantin (pengantin haguet) pada waktu sebelum keberangkatan bersamasama seluruh keluarga, pengantin laki-laki duduk sambil menunggu keluarga yang lain untuk bersiap-siap, suasana sangat ramai karena dipenuhi oleh undangan serta keluarga yang ingin ikut mengantar saat keberangkatan dilaksanakan pada sore hari. Kemudian dilanjutkan dengan sebutan Pengantin Lumpat Pada acara penganten lumpat/ manyakey. Barang-barang yang telah dipersiapkan kemudian dibawa dengan cara digendong. Ini dimaksudkan bahwa dalam hari pernikahannya penganten ini akan diangkat, diagungkan sebagai raja sehari.

\section{Paris Langkis}


Dibarengi juga dengan lantunan atau iringan doa-doa memohon doa restu kepada Tuhan Yang Maha Esa untuk melidungi perjalanan penganten dari keberangkatan sampai selesai acara pernikahan nanti. Ketika penganten laki-laki sudah sampai di halaman rumah perempuan, sudah ada penyambutan dari mempelai perempuan di mana di halaman rumah sudah dibuat semacam pintu gerbang dari pelapah daun kelapa yang dirintangi dengan benang atau tali. Pintu gerbang ini dinamakan lawang sakepeng. Sebelum mempelai melewati pintu gerbang untuk masuk ke rumah keluarga mempelai perempuan makna benang / tali perintah itu terlebih dahulu diputuskan oleh sepasang atau beberapa pasang ahli pencak silat (tergantung dari berapa jumlah pintu gerbang yang disediakan).

Acara lawang sakepeng sebenarnya sudah menjadi kebiasaan untuk memeriahkan suasana menyambut mempelai laki-laki. Tujuan dari lawang sakepang ini adalah untuk menjauhkan semua rintangan dan malapetaka yang dapat menimpa calon suami-istri didalam membina kehidupan bersama kelak di kemudian hari. Dengan diiringi suara gong setelah tali mampu diputuskan berarti penghalang sudah tidak ada dan kedatangan calon mempelai laki-laki disambut dengan lahap berturut-turut (lahap = adalah pekik rimba yang berarti kegembiraan dan kesungguhan hati mereka akan suatu tekat dan tujuan yang telah mereka sepakati bersama).

Tali atau benang sudah putus berarti merupakan simbol bahwa segala rintangan dan persoalan yang dihadapi suami istri dalam kehidupan berumahtangga, akan dapat diatasi apabila suami istri senantiasa rukun, bekerja sama dan saling membantu. Pada saat penganten masuk kemudian menginjak telur ayam yang telah disediakan, (tidak dilaksanakan) simbol dari telur ini adalah diibaratkan hidup seperti telur yang diawali dengan putih bersih dan sebagai pendingin agar hidup tidak ada rintangan, setelah itu penganten laki-laki ditampung tawar (dipercikkan air dengan menggunakan daun sawang) dengan memakai daun sawang yang telah gugur, ini dimaksudkan untuk menjauhkan segala marabahaya dari mempelai.

Pada saat ditampung tawar, mula-mula penganten menghadap ke arah matahari terbenam ini sebagai simbol bahwa semua marabahaya serta segala sesuatu yang membawa sial dibuang. Sama seperti matahari terbenam maka demikian juga segala sesuatu itu juga ikut hilang terbenam. Kemudian setelah itu penganten menghadap lagi ke arah matahari terbit, yang berarti sebagai simbol matahari terbit maka segala untung dan rezeki datang kepada mempelai di dalam membina rumah tangga mereka. (tamping tawar dengan daun sawang diganti dengan bunga- bungaan dan wangian yang ditaburkan ke atas menyambut calon pengantin laki-laki).

Di dalam rumah pada saat penganten laki-laki sudah duduk dan kedua keluarga telah berkumpul maka dari pihak laki-laki dengan diwakili oleh mantir atau pihak keluarga dekat yang memimpin acara memberikan paramun pisek (syarat-syarat perkawinan) kepada orang tua pihak perempuan. Kemudian barang yang telah diterima keluarga perempuan tersebut secara bersama-sama diangkat melebihi batas kepala, hal ini melambangkan bahwa kehidupan nantinya akan ringan, bagus, beruntung, berezeki baik itu dalam masyarakat, keluarga dan sebagainya. Setelah penyerahan barang paramun pisek diserahkan kepada pihak perempuan, kemudian acara pesta kecil berupa makan secara sederhana.

\section{Prosesi Pasca Perkawinan Menurut Adat Dayak Ngaju Di Kecamatan Timpah Kabupaten Kapuas}


Setelah melalaui beberapa tahapan proses adat perkawinan dalam suku Dayak Ngaju masih ada satu tahapan prosesi akhir adat yaitu pasca perkawinan yang dikenal masyarakat Dayak pada umumnya yaitu dengan sebutan Pakaja Manantu seperti yang dikemukakan oleh Damang Kecamatan Timpah Kabupaten Kapuas mengatakan: "Benar bahwa setelah perkawinan dilakukan ada satu tahapan proses adat pada Dayak Ngaju yaitu Pakaja Manantu”.(Wawancara, 19 Mei 2019). Hal di atas juga sejalan dengan yang dikemukaka oleh Bapak Model Selaku Mantir Adat mengatakan "Dilakukannya pakaja menantu merupakan serangkaian dari adat istiadat leluhur yang harus dilestarikan. Namun Pakaja Manantu pada dasarnya jika tidak dilakukan juga tidak memiliki sanksi adat, tergantung kesepakatan kedua belah pihak keluarga". (Wawancara, 12 Mei 2019).

Dari hasil wawancara di atas dapat dijelaskan bahwa diujung pesta perkawinan adat Dayak Ngaju pasca perkawinan dilaksanakan ada satu tahapan yang bisa dilalui dan bisa juga tidak dilaksanakan tergantung kesepakatan antar kedua belah pihak keluarga melaksanakan pakaja manantu atau tidaknya karena juga tidak memiliki efek atau sanksi namun pakaja manantu merupakan bagian dari jalannya adat budaya Dayak yang juga mempunyai arti bahwa pengantin perempuan beserta keluarga besar berkunjung kerumah pihak laki-laki dengan berbagai rangkaian dan tujuan mulai dari menjalin silaturahmi kepada keluarga laki-laki hingga ibadah ucapan syukur (kebaktian).

Dengan demikian apabila jika ada yang melanggar/membatalkan perkawinan adat Dayak Ngaju yang telah berlaku dan sudah ikut campur adat maka akan ada sanksi dan denda seperti panggul yang sudah tertulis seperti yang dikemukakan oleh Damang Kecamatan Timpah Kabupaten Kapuas mengatakan : "pelanggaran itu akan selalu ada selama masih memakai dan memenuhi dan tunduk dengan aturan yang sudah ada da nada sanksi yang akan diberikan dan apabila dia tidak memakai pelaturan adat dia harus mengikuti pelaturan itu begitujuga yang melakukan perkawinan diluar adat itu terserah seperti apa yang berlaku dari mereka'dan tidak memiliki surat dan segala kerugian tak akan bias dituntut". (Wawancara, 23 Agustus 2019).

Berdasarkan hasil wawancara dan hasil pengamatan yang dapat peneliti delama tinggal di Kecamatan Timpah Kebupaten Kapuas mengenai pelaturan yang telah ditetapkan oleh adat Dayak Ngaju apabila sudah terjadi Hapanggol adan itu artinya sudah ada ikut campur tangan Dewan Adat dan ketentuan yang berlaku harus sesuai dengan apa yang telah tertulis dan apabila salah satu membatalkan maka yang melakukan pembatalan akan dikenakan denda dan sanksi sesuai dengan yang berlaku dan tertulis waktu Hapanggol yang sudah di setujui oleh kedua pasangan dan keluarga. Kemudian hal diatas juga sejalan dengan apa yang dikatakan oleh Mantir adat di Kecamatan Timpah Mengatakan "apabila dilakukan hapanggol hal itu dilakukan melalui hal yang sudah tertulis didalam surat dan disepakati oleh calon mempelai danke dua belah keluarga yang bersangkutan dan barang siapa yang melanggar atau melakukan penghianatan sehingga terjadinya pembatalan maka hal itu pihak yang membatalkan akan membayar dan dikenakan sanksi sesuai dengan apa yang tertulis di selembar kertas yang telah di setujui, dan apabila melakukan perkawinan secara adat dan adat tidak akan ikut campur untuk hal ini dan bila ditanyakan mengenai hal yang rugi mereka dan adat tidak akan berani untuk campur tangan, dan yang melanggar adat dalam perkawinan juga sering terjadi hal yang membuat salah satu berpaling dan terjadinya pembatalan ini tadi. Dan bagi kami sebagai dewan adat yang menjadi kendala/penghambat bagi kami sebagai lembaga hanya menjalankan tugas sesuai dengan ketentuan yang sudah berlaku dan melakukan sesuai surat yang sudah terjadi semua itu sesuai dengan ketentukan keluarga itu sendiri". (Wawancara, 22 Agustus 2019).

\section{Paris Langkis}




\section{E. KESIMPULAN}

Pelaksanaan Perkawinan Adat Dayak Ngaju merupakan suatu perkawinan yang dilakukan pada umumnya kebanyakan orang, namun mempunyai keunikan dan keragaman yang berbeda mulai dari proses dan tahapan awal hingga prosesi akhir pasca perkawinan dengan tujuan, fungsi, dan syarat perkawinan menurut Adat Dayak Ngaju yang dapat disimpulkan.

1. Proses pelaksanaan perkawinan Adat Dayak Ngaju memiliki tahapan dan langkahlangkah yang perlu dilalui seperti yang pertama yaitu, yang pertama ini Hakumbang Auh adalah proses dimana lamaran dimulai dengan memberikan sebuah duit pangumbang sebagai bentuk komunikasi dan pesan kepada seorang yang akan dilamar, Mamanggul merupakan tahap lanjutan dari Hakumbang Auh cara meminta si gadis secara resmi setelah pihak pria mengetahui bahwa keinginan hati di terima dan selanjutnya akan dilakukan Maja Misek (Peminangan) yang berarti bertamu pada tahap ini dilakukan kesepakatan kapan waktu pelaksanaan perkawinan dan kepastian hari tanggal dan tempat dibicarakan dan disepakati kedua belah pihak. tahapan yang kedua adalah mamanggul/mamupuh dan perjanjian perkawinan masih dilakukan karena didalamnya terdapat nilai-nilai sosial dalam masyarakat. Tahap Ketiga, perjanjian perkawinan mengandung aturan-aturan mengenai hak dan kewajiban antara seorang suami dan istri dan ditahap ini memiliki beberapa tingkat seperti Penganten Manda'i, arak-arakan yang dilakukan disiang hari, dan lanjut pada malam harinya akan dilaksanakan upacara Haluang Hapelek atau yang biasa disebut dengan pemenuhan Hadat Jalan antara lain Palaku. Dan tahap terakhir menurut Adat Dayak Ngaju yaitu Pakaja Manantu yang dilakukan dirumah mempelai pria untuk pengenalan dengan keluarga pihak pria dan sebagai ucapan syukur dari pihak keluarga pria. Dan apabila Aturan-aturan itu disertai dengan sanksi yang tegas sebagai akibat jika terjadi pelanggaran terhadap aturan tersebut.

2. Tahapan selanjutnya dari kedua belah pihak harus mengetahui tujuan, fungsi dan syarat perkawinan yang sesuai menurut Adat Dayak Ngaju. Dan Tujuan dari sebuah perkawinan adalah menyatukan dua hati dan raga yang tak sedarah untuk saling menuju jenjang yang lebih serius. Syarat-syarat yang harus dipenuhi adalah mendapat restu dari kedua keluarga calon mempelai, umur yang telah dewasa dan memiliki tanggung jawab bila mereka telah melaksanakan perkawinan menurut adat dan apabila dari antara mereka melakukan kesalahan dan membatalkan tahapan perkawinan yang telah melalui adat maka yang melakukan pembatalan ini akan diberikan sanksi yang tegas sebagai akibat jika terjadi pelanggaran.

3. Tahapan selanjutnya pelaksanaan prosesi pasca perkawinan yang dimulai dari pengantin Haguet dan pengantin lumpat hingga pasca perkawinan dilaksanakannya pesta dan prosesi pakaja menantu dimana pihak pengantin perempuan yang berkunjung kerumah pihak laki-laki sebagai ucapan syukur dan pengenalan lebih jauh ke pihak keluarga lelaki. 


\section{REFERENSI}

Eddy Lion dan Halmuth (2013). Metode Penelitian Kuantitatif. Yogyakarta, Pustaka antara Surabaya

Gunarsa SD, Gunarsa YSD, (2007). Psikologi Praktis: Anak, Remaja dan Keluarga. Jakarta (ID): Gunung Mulia

Hadiwijoyo, Erekso, dkk. (2017). Kearifan Lokal Masyarakat Dayak Ngaju Di Kalimantan Tengah Dalam Melakukan Penyiapan Lahan Dengan Pembakaran. Jurnal Silvikultur Tropika Vol. 08 No. 1, April 2017, Hal 1-8

Harun Hadiwijono, (2012). Religi suku Murba di Indonesia .Jakarta : BPK Gunung mulia.

Matondang, A. (2014). Faktor-faktor yang Mengakibatkan Perceraian dalam Perkawinan. JPPUMA: Jurnal Ilmu Pemerintahan Dan Sosial Politik UMA (Journal of Governance and Political Social UMA).

Nina Putri Hayam Dey, Sri Suwartuningsih dan Daru Purnomo, (2012). “Aspek Budaya, Sosial dan Ekonomi dari Tiwah (Upacara Masyarakat Dayak Tomun Lamandau), Jurnal Studi Pembangunan Interdisiplin, Vol XXI no. 2

Normuslim, N. (2018). Kerukunan Antar Umat BeragamaKeluarga Suku Dayak Ngaju di Palangka Raya. Wawasan: Jurnal Ilmiah Agama Dan Sosial Budaya. https://doi.org/10.15575/jw.v3i1.1268

Nurhajati, L., \& Wardyaningrum, D. (2014). Komunikasi Keluarga dalam Pengambilan Keputusan Perkawinan di Usia Remaja. Jurnal AL-AZHAR Indoensia Seri Pranata Sosial. https://doi.org/10.1109/ROBOT.1997.620145

Saefulloh, A. (2018). Rehabilitasi Eks-Pecandu Narkoba Melalui Pendekatan Agama Islam. ISLAMIC COUNSELING: Jurnal Bimbingan Konseling Islam, 2(1), 43. https://doi.org/10.29240/jbk.v2i1.377

Santoso. (2016). Hakekat perkawinan menurut undang-undang perkawinan, hukum islam dan hukum adat. Yudisia.

Sugiyono, (2009). Metode Penelitian Pendidikan Pendekatan Kuantitatif, Kualitatif dan R \& D. Bandung : PT. Alfabeta

Sugiyono, (2012) Metode Penelitian Pendidikan Pendekatan Kuantitatif, Kualitatif dan R \& D. Bandung : PT. Alfabeta

Tim Penulis Departemen Pendidikan dan Kebudayaan, (2016) Adat dan Upacara Perkawinan Daerah Kalimantan Timur, (Jakarta: PN Balai Pustaka, tanpa tahun), Hal. 14-15 
Darlok Vennyco, 2013. Pelaksanaan Perkawinan Adat Dayak Jangkang Di Desa Jangkang Benua Kecamatan Jangkang Kabupaten Sanggau.Jurnal IHP UNTAN Volume 1 Nomor 2 hal. 6

Wiwi Noviana, (2008). Proses Komunikasi Budaya dalam Upacara Perkawinan Adat DayakNgaju di Kotamadya PalangkarayaProvinsi Kalimantan Tengah. Surakarta: Universitas Sebelas Maret

Departemen Pendidikan dan Kebudayaan. (2017). Hal, 32-33

Dewan Adat Dayak Kapuas Kalimantan Tengah Tahun, (2008). Hukum Adat Dayak Ngaju. Kabupaten Kapuas

Dewan Adat Dayak Kota Palangka raya, (2018). Pedoman Penyelenggaraan dan Penegakan Hukum Adat Dayak Ngaju Wilayah Kedemangan Palangka Raya. 